\title{
Foreign Direct Investment and Economic Growth in Nigeria (1986 - 2017)
}

\author{
Badmus, Wasiu Alao* \\ Accountancy Department, Osun State College of Technology, PMB 1011, Esa-Oke \\ Oyekanmi, Adewale Oladipo, $\mathrm{PhD}$ \\ General Studies Department, Osun State College of Technology, PMB 1011, Esa-Oke
}

\begin{abstract}
Foreign Direct Investment (FDI) has attracted the attention of many developing countries. Hence, the study examined the effects of Foreign Direct Investment on economic growth and captured the impacts of other macroeconomic variables on economic growth in Nigeria between the period of 1986-2017. The secondary data used in this study were obtained from Central bank of Nigeria (CBN) Statistical Bulletin and World Development Indicator (WDI). To avoid spurious regression, Augmented Dickey Fuller unit root test was conducted on all variables. Multiple regression and Granger Causality Test were also conducted to target the study objectives. The multiple regression reveals that Foreign Direct Investment is statistically significant at $5 \%$ level of significance. Thus, Foreign Direct Investment has a significant effect on economic growth in Nigeria. The Granger Causality Test also confirms that Foreign Direct Investment Granger causes economic growth in Nigeria. The conclusion is that Foreign Direct Investment has a positive and significant effect on economic growth. It also Granger causes economic growth in Nigeria. There is high prospect for Foreign Direct Investment to further boost economic growth if enabling environment such as regular infrastructure and microeconomic stability prevail in Nigeria.
\end{abstract}

Keywords: Foreign Direct Investment, Economic growth, Granger causality.

DOI: $10.7176 /$ RHSS/10-6-06

Publication date:March $31^{\text {st }} 2020$

\section{Introduction}

Various policies of the Nigeria government have been directed towards sustaining economic growth and attainment of economic development by stimulating the flow of foreign finance into the economy. According to United Nations Conference on Trade and Development (UNCTAD 2006), Nigeria remains one of the largest recipients of FDI in Sub-Saharan Africa. Nigeria received 11\% of Africa's total inflow of FDI in 2006 and 70\% of West Africa's total inflow of FDI. Oil however accounted for $80 \%$ of the total inflow of FDI into Nigeria.

The common applications of Foreign Direct Investment are the establishments of new companies in high profit business areas or the purchase of an already existing company in this foreign country. In such investments, the management and the control of the investment are mostly carried out by the foreigners. According to the proponents of Foreign Direct Investment, the higher the amount of foreign investment a country can attract the bigger the portion it can take from global production and income, therefore, its national wealth can increase (Guraks, 2003).

The empirical relationship between FDI and economic growth in Nigeria is yet unclear, despite numerous studies that have examined the influence of FDI on Nigeria's economic growth with varying outcome (Adelegan 2000, Asiedu 2003, Akiwo 2004). Most of the previous studies on FDI and economic growth in Sub-Saharan Africa are multi-country studies. However, recent evidence affirms that the relationship between FDI and economic growth may be country specific. Hence, this study is country specific by examining the empirical evidence from Nigeria.

This study is neccessary because of the divergent view of scholars on the need of foreign direct investment as a veritable booster of Nigeria economy. Some believes Foreign Direct Investment is a form of neo-colonialism while other believes is a catalyst to growth and development.

The poor state of infrastructure in Nigeria especially the prevailing epileptic power supply across the country has also been identified as a serious impediment to the realization of FDI goals and objectives. Hence, the inclusion of infrastructure as a variable in this empirical study has not been properly focused by previous studies. It is therefore necessary for further studies to be carried out on FDI and economic growth in Nigeria. It is also important to verify which one granger causes the other.

\subsection{Problem Statement / Justification}

In Nigeria, the ability to sustain growth and meet its external obligations depends on adequate inflow of foreign investment resources, given low level of per capita real income, high average and marginal consumption propensities, low savings and restricted new productive capital formation. It is discovered that there exists a gap between the domestically available supply of savings, foreign exchange and planned level of these resources 
necessary to achieve growth targets (Todaro, 2000). From this claims, the contribution of Foreign Direct Investment (FDI) to Nigeria remained doubtful. Hence, this paper attempts to full this vacuum.

According to Okeke, Ezeabasili and Nwakobi (2014), "the federal governments of Nigeria and the monetary authority have adopted several policies, strategies and innovations to open up the economy, improve infrastructural facilities, provide tax inducement like tax holiday for infant industries, and reduction in import tariff to improve the inflow of Foreign Direct Investment into Nigeria economy". But the macro question here is whether these measures have improved the FDIs impact positively on the Nigeria economy.

In consideration of studies conducted in Nigeria, whether Foreign Direct Investment leads to economic growth is still debatable. What is clear is that the relationship may be significant or insignificant depending on the country under study, type of investments, the implementation policy of the recipient country, the methodology used, and the period of study (Musau, 2009)

One basic issue on Foreign Direct Investment (FDI) into less developed countries (LDCs) is its impact on the various sectors of the economy. While there is consensus on the determinant of FDI, Its specific effects on the economy remains an empirical issue. Most often scholars do assume that since there is prevalent resources gap in LDCs then Foreign Direct Investment will definitely promote growth in the economy. This is a serious contentious issue.

A study like this has become imperative to ascertain the extent at which FDI affects economic growth, and the direction of causality and the long run relationship among some specified macroeconomic variables.

It is pertinent to note that, the bulk of research studies carried out so far on the Foreign Direct Investment have been on the determinants of Foreign Direct investment with little efforts to examine their relative impact on economic growth over the years. Where the impact is examined, they are commonly based on cross country data. Where it was based on country specific data, the examination of the FDI effect do not cover a recent data as done in this study (1986-2017) and the inclusion of infrastructure as one of the macroeconomic variables which hitherto has not been deeply investigated.

Studies conducted on FDI and economic growth in Nigeria still remain unclear as they arrive at varying outcome which means the results on those studies are still debatable.

There is therefore an apparent gap in the stock of knowledge in the area of (FDI) and economic growth in Nigeria. This study aims at filling this gap and attempt will be made to evaluate government policies and incentives so as to serve as a guideline for future policy formulation

The overall objective of this study is to investigate the effects of Foreign Direct Investment on economic growth in Nigeria from 1986 to 2017. The specific objectives of this research is to examine the direction of Causality between Foreign Direct Investment (FDI) and Economic Growth (GDP) in Nigeria.

\section{Literature Review}

Jhingan (2002), defines economic growth "as the process whereby the real per capital income for a country increases over a long period of time". He states that economic growth is measured by increase in the amount of goods and services in each successive time period. Thus, growth occurs when an economy's productive capacity increase which in turn is used to produce more goods and services. It is in view of this that foreign direct investment (FDI) has been seen as being potent for growth.

Foreign direct investment (FDI) is "the category of International Investment in which an enterprise resident in one country (direct investor) acquires an interest of at least $10 \%$ in an enterprise resident in another country" (UNCTAD 2010).

FDI can also be defined "as an increase in the book value of the networth of investment in one country held by investors of another country where the investments are under the managerial and control of the investor" (Graham, 2000). To buttress the definition above, Todaro and smith (2003) noted that, most FDI are the parent organization of firms. Thus, foreign direct investment flows represent the expansion of the international activities of Multinational Corporations.

\subsection{Theoretical Review}

Mankiw (2003) applying the Solow growth model argues that private businesses invest in traditional types of capital such as bulldozers and steel plants and newer types of capital such as computers and robots. On the other hand, government invests in various forms of public capital, called infrastructure, such as roads, bridges and sewer systems. Mankiw further argues that policy makers trying to stimulate growth must confront the issue of what kinds of capital the economy needs most. In other words, what kind of capital yields the highest marginal products?

According to neoclassical theory, FDI influences income growth by increasing the amount of capital per person. It spurs long-run growth through such variables as research and development (R\&D) and human capital. Through technology transfer to their affiliates and technological spillovers to unaffiliated firms in the host economy, MNCs can speed up the development of new intermediate product varieties, raise product quality, facilitate international collaboration on R\&D, and introduce new forms of human capital (Ikiara, 2003). 
Bajona \& Kehoe (2006) discussed explanations of multinational production based on neoclassical theories of capital movement and trade within the Hecksher-Ohlin framework. However, they criticize these theories on the basis that they were founded on the assumption of existence of perfect factor and goods markets and were therefore unable to provide satisfactory explanation of the nature and pattern of FDI. In the absence of market imperfections, these theories presumed that FDI would not take place. Nevertheless, they argue that the presence of risks in investing abroad implies that there must be distinct advantages to locating in a particular host country.

\subsection{Empirical review}

Having review the theoretical aspect of FDI, it is necessary to take a look at some important empirical contributions based on the observation of rate of significance and controversy regarding FDI especially in the resent past all over the world.

According to Carkovic and Levine (2003), Todaro and Smith (2003), FDI now accounts for over sixty percent $(60 \%)$ of private capital flows. The flow of foreign direct investment (FDI) from organization for Economic Cooperation and Developed Countries (OECD) has been extremely rapid with an average of about $\$ 4.5$ billion in 1996, up from an average of US \$3.8 billion in 1991-1995 (World Bank 1997). Africa received about 5\% of total FDI flows and FDI capital goes mainly into mineral extractions that is the petroleum industry, manufacturing and mining. While the explosion of FDI flows is unmistakable, the growth effect remains unclear (Carkovic and Levine 2002).

In terms of the contributions of FDI to a Nigeria economy, two schools of thought emerged; the pro-foreign investment advocate. This group believes FDI is beneficial to host countries and the world through the transmission of technology, ideas, designs, taste and better management ( Oloyede and Obamuyi 2000). The benefits from FDI also include filling saving resources gap. Foreign exchange gap and balance of payment.

On the other hand, the anti-foreign investment approach associate themselves with the cost of FDI to host countries and assert that FDI damages host economies by suppressing domestic entrepreneurships, introduction of unsuitable products and technology, subjecting host countries to exploitation and stimulating class conflict leading to negative contribution ( Oloyede and Obamuyi 2000).

In reconciling the pros and cons of the role of MNCs who provide foreign direct investment (FDI) capital and Todaro and Smith (2003) asserts that the above list provides a range or conflicting arguments, the real debate ultimately centers on different ideological and value judgments about the nature and meaning of economic growth and development and the principal sources from which it springs. However, the only valid conclusion is that foreign private investment may be an important stimulus to economic growth and social development as long as the interest of MNCs and host countries government coincide and that MNCs who provide FDI capital adopt a long-run perspective by adapting their technologies of production to the resources of developing nations.

$\mathrm{Li}$ and Liu (2005) use the panel data of 84 countries to investigate the effect of FDI on economic growth. The study found a significant relationship between FDI and economic growth. Additionally, a stronger relationship was extracted when FDI is interacted with human capital.

The reason is as a result of stronger human capital poses better absorptive capacities due to the complementary nature of the FDI and human capital, most importantly for the developing countries.

Marwah and Tavakoli (2004) examined the effect of FDI and imports on economic growth in four countries. The elasticity of the estimated production function of FDI was found to be significant in explaining the economic growth of all the four countries. Adewumi (2006) examined the contribution of FDI to economic growth in Africa using annual series, by applying time series analysis from 1970 to 2003 . He found that FDI contributes positively to economic growth in most of the countries but it is not statistically significant.

For studies conducted in Nigeria, Fasanya (2012) postulated that despite the increased capital flows to African countries, including Nigeria, many African countries are still characterized by low per-capita income and high unemployment rates, foreign direct investments are theoretically and empirically supposed to solve these problems. The Nigerian government has been focusing on policies that will help attract foreign investors and yet the economy is still dwindling. In line with this background, he study the impact of foreign direct investment on economic growth in Nigeria for the period 1970-2010 making use of annual time series data through a neo-classical framework. The findings show that foreign direct investments have positive impact on economic growth in Nigeria and so does domestic investment. The study recommends that for Nigeria to effectively reap the benefits of foreign and domestic investments, its economic planners should create a healthy and enabling business environment that encourages both foreign and local investors, provide incentives for innovation and skills improvement, and contributes to competitive corporate climate.

Akinlo (2004) investigated the impact of foreign direct investment (FDI) on economic growth in Nigeria, for the period 1970-2001. Employing ECM results show that both private capital and lagged foreign capital have small and statistically insignificant effect on the economic growth.

The findings support the argument that extractive FDI might not be growth enhancing as much as manufacturing FDI and conclude that growth would be enhanced if FDI inflows are channelled into sectors other 
than the oil sector. Therefore Government needs to provide appropriate environment to attract manufacturing FDI.

Ayanwale (2007) investigated the empirical relationship between nonextractive FDI and economic growth in Nigeria and also he examined the determinants of FDI inflow into the Nigerian economy for the period 1970 to 2002. The augmented growth model was estimated via the ordinary least squares and the 2SLS method to ascertain the relationship between the FDI, its components and economic growth. The study reveals that the main determinants of FDI in Nigeria are market size (proxied by GDP), stable macroeconomic policies and a level of human capital that is tolerable by investors. The study reported that FDI contributes positively to Nigeria's economic growth and that the FDI in the communication sector currently has the highest potential to grow the Nigeria economy, especially the non-oil sector. Furthermore the FDI in the manufacturing sector has a negative relationship with economic growth, suggesting that the business climate is not healthy enough for the manufacturing sector to thrive and contribute positively to economic growth.

Studies conducted on FDI and economic growth in Nigeria still remain unclear as they arrive at varying outcome which means the result on those studies are still debatable. Hence, the need for this study.

\section{Data and Methods of Research:}

This study aims to empirically investigate the effect of Foreign Direct Investment (FDI) on economic growth in Nigeria for 32 years period. To achieve this aim, the study adopted a time series research design.

Secondary source of data were used in this research with the data obtained from Central Bank of Nigeria (CBN) Statistical Bulletin. The research covered the period 1986 to 2017 (32 years).

To test the effect of Foreign Direct Investment (FDI) on economic growth in Nigeria, the paper adopted multiple regression analysis of Ordinary Least Square (OLS). The unit root test was first conducted to examine the level of stationarity of each variable. The variables are stationary at level I(0) and there is no need for Cointegration test. The Augmented Dickey Fuller unit root test was conducted to avoid a spurious regression. Granger Causality Test shows the direction of causality between FDI and GDP. The Serial Correlation Test and residual normality test were also conducted. These tests were conducted via E-VIEWS 9 package.

\subsection{Empirical Model Formulation :}

It is important to consider several macroeconomic variables in this study because of the divergent views of scholars on the need of Foreign Direct Investment as a veritable booster of Nigeria Economy. This will show the significance of other variables on the economic growth apart from FDI. For the purpose of this study; Gross Domestic Product (GDP) proxied Economic Growth stands as dependent variable while Foreign Direct Investment (FDI), Export (EPT), Exchange rate (EXR), Infrastructure (INF) are independent variables. These macroeconomic variables were considered to present a moderate result that will adequately reflect the impact of each variable apart from FDI. The model specification is as follows:

$\mathrm{GDP}=\mathrm{f}(\mathrm{FDI}, \mathrm{EPT}, \mathrm{EXR}, \mathrm{INF})$

$\mathrm{GDP}=\beta_{0}+\beta_{1} \mathrm{FDI}+\beta_{2} \mathrm{EPT}+\beta_{3} \mathrm{EXR}+\beta_{4} \mathrm{INF}+\mathrm{U}_{\mathrm{t}}$

The log of the variables was taken so that all observations in each variable will have equal weight so as to avoid serial auto correlation since the data covered a long period of 30 years.

It becomes:

$\begin{array}{lll}\text { LGDP }=\beta_{0}+\beta_{1} \text { LFDI }+ & \beta_{2} \text { LEPT } & +\beta_{3} \text { LEXR }+\beta_{4} \text { LINF }+\mathrm{U}_{\mathrm{t} \ldots \ldots \ldots \ldots \ldots \ldots \ldots . .(3)} \\ \text { Where : } & = & \text { Gross Domestic Product (Proxied Economic Growth) } \\ \text { GDP } & = & \text { Foreign Direct Investment } \\ \text { FDI } & = & \text { Export } \\ \text { EPT } & = & \text { Infrastructure (measured by Electricity consumption, Kwh) } \\ \text { EXR } & = & \text { Log of GDP } \\ \text { INF } & = & \text { Log of FDI } \\ \text { LGDP } & = & \text { Log of Export } \\ \text { LFDI } & = & \text { Log of Exchange rate } \\ \text { LEPT } & = & \text { Log of Infrastructure. } \\ \text { LEXR } & = & \text { Error term } \\ \text { LINF } & = & \text { Intercept or Constant. } \\ \mathrm{U}_{\mathrm{t}} & = & \text { Coefficients to be estimated. } \\ \beta_{0} & & \end{array}$

\section{Analysis and Interpretation of Results.}

4.1 Stationarity Test

To avoid spurious regression result, the test for stationarity of all variables were conducted to obtain a reliable result. The result of Augmented Dickey-Fuller (ADF) test of all the variables are as reported in Table 1 below. 
Table 1: Augmented Dickey-Fuller (ADF) Unit Root Test for variables between 1986 and 2017

\begin{tabular}{|l|l|l|}
\hline Variables & t-statistics & Order of integration \\
\hline GDP $=$ LGDP $* * *$ & -1.880812 & $\mathrm{I}(0)$ \\
\hline FDI $=$ LFDI $* *$ & -0.839993 & $\mathrm{I}(0)$ \\
\hline EPT $=$ LEPT $^{* * *}$ & -3.238267 & $\mathrm{I}(0)$ \\
\hline EXR $=$ LEXR $^{* * *}$ & -2.612963 & $\mathrm{I}(0)$ \\
\hline $\mathrm{INF}=\mathrm{LINF}^{* *}$ & -0.075334 & $\mathrm{I}(0)$ \\
\hline
\end{tabular}

Source: Author's Computation, 2019

Note: *** Significant at 1 percent level of significance

The result in Table 1 above shows that all the variables are stationary at level I(0). i.e order of integration of zero. This implies there was no unit root and the Ordinary Least Square (OLS) regression can be run. The need to verify the long run relationship otherwise known as Johansen's Co-integration test do not arise.

\subsection{Ordinary Least Square Estimation}

To be able to capture the essence of the work effectively, this study conducted an Ordinary Least Square (OLS) multiple regression because of its simplicity and global acceptability summary of the result is shown in Table 2 below.

Table 2: Ordinary Least Square regression result

\begin{tabular}{|l|l|l|l|l|l|l|l|l|}
\hline Variables & Coefficient & S/D Error & t-statistic & Prob & $\begin{array}{l}\text { R- } \\
\text { Squared }\end{array}$ & F-statistic & $\begin{array}{l}\text { Prob } \\
\text { F-stat }\end{array}$ & $\begin{array}{l}\text { Durbin } \\
\text { Watson }\end{array}$ \\
\hline Constant & 1.44066 & 0.25297 & 5.69493 & 0.0000 & & & & \\
\hline LFDI & 0.22207 & 0.09782 & 2.27025 & 0.0321 & & & & \\
\hline LEPT & 0.54561 & 0.09561 & 5.70664 & 0.0000 & 0.99058 & 657.455 & 0.0000 & 1.5833 \\
\hline LEXR & 0.03177 & 0.09564 & 0.33222 & 0.7425 & & & & \\
\hline LINF & 0.89646 & 0.16991 & 5.27596 & 0.0000 & & & & \\
\hline
\end{tabular}

Source: Author's Computation, 2019

$\mathrm{LGDP}=1.44+0.22 \mathrm{LFDI}+0.546 \mathrm{LEPT}+0.03 \mathrm{LEXR}+0.896 \mathrm{LINF}$

The OLS result in Table 2 shows that Foreign direct Investment, Export, Exchange rate and Infrastructure have positive effect on Economic growth. An increase in Foreign Direct Investment will cause a 22\% increase in Economic Growth. An increase in Export will bring about 54.6\% increase in Economic Growth, Exchange rate and Infrastructure contribute $31.8 \%$ and $89.6 \%$ respectively to any slight increase in economic growth.

Only Exchange Rate (LEXR) is not statistically significant with P-value of 0.7425 . Foreign Direct Investment (LFDI) has a p-value of 0.0321, Export (LEPT) has a p-value of 0.000 and infrastructure has a p-value of 0.0000

The three variables are statistically significant. The R-Squared of 0.99058 implies $99.1 \%$ of the variation in economic growth (GDP) are explained by the explanatory variables within this model less than $1 \%$ are caused by other variables not included in the model but explained by the error term.

The Durbin Watson of 1.6 is close to 2; this connoted the assence of first anto correlation in the regression model. Thus, we can make valid prediction (s) with the OLS equation in equation 4 above.

The F statistics of 657.45 is significant at 5\% level of significance. The statistical index of Foreign Direct Investment reject the Null hypothesis since LFDI p-value is less than 5\%. Hence, it implied Foreign Direct Investment has a significant effect on Economic growth.

\subsection{Granger Causality Test:}

It is pertinent to examine the direction of causality between Foreign Direct Investment and economic growth in Nigeria, since both could aid each other. Table 3 below shows the result of Granger Causality Test conducted to examine which variable actually Granger Cause another.

Table 3:

Pairwise Granger Causality Tests

Date: 03/13/19 Time: 20:11

Sample: 19862017

Lags: 2

\begin{tabular}{lccr}
\hline \hline Null Hypothesis: & Obs & F-Statistic & Prob. \\
\hline \hline LGDP does not Granger Cause LFDI & 30 & 6.65082 & 0.0053 \\
LFDI does not Granger Cause LGDP & & 1.60500 & 0.2226 \\
\hline \hline
\end{tabular}

Source: Author's Computation, 2019 
The table 3 above disclosed that Foreign Direct Investment (LFDI) actually Granger Cause Economic Growth (LGDP). The p-value of 0.2226 which is greater than 0.05 level of significance confirm this. This is synonymous with the result of ordinary least square and conform with ap-riori expectation.

\section{Conclusion and Recommendations}

From the findings above, the multiple regression reveals that Foreign Direct Investment with p-value of 0.00321 is statistically significant at 5\% level of significance. Thus, Foreign Direct Investment has a significant effect on economic growth in Nigeria. The Granger Causality Test also confirms that Foreign Direct Investment Granger cause economic growth in Nigeria. The conclusion is that Foreign Direct Investment has a positive and significant effect on economic growth. It also Granger causes economic growth in Nigeria. There is high prospect for Foreign Direct Investment to further boost economic growth if enabling environment such as regular infrastructure and macroeconomic stability prevail in Nigeria.

\section{References}

Adelegan, J. O. (2000). "Foreign Direct Investment Domestic Investment and Economic Growth in Sub-Saharan Africa". Journal Policy Modelling. 31(6) 939 - 949.

Akinlo, A. E. (2004). "Foreign Direct Investment and Growth in Nigeria. An Empirical Investigation". Journal of Policy Modelling 26(5), 627-639.

Asiedu, E. (2003. "On the Determinants of Foreign Direct Investment to developing countries: Is Africa Different?". World Development 30(1), 107-119.

Ayanwale, A. B (2007). "FDI and Economic Growth: Evidence from Nigeria". African Research Consortium, Nairobi.

Bajona, C \& Kehoe, T. J (2006). "Trade, Growth and Convergence in a Dynamic Heckscher - ohlin Model". National Bureau of Economic Research (NBER). Working Paper No. 12567 pg 1-4.

Brooks, C (2008). "Introductory Econometric for Finance”. Cambridge University Press pp. 20-32.

Buckley, P. J \& Casson, M. C (1998. “Analysing Foreign Market Entry Strategies: extending the Internalization Approach". Journal of International Business Studies, 29(3), 539-562.

Carkovic, M. \& Levine, R. (2002). “Does Foreign Direct Investment Accelerate Economic Growth?”. University of Minnesota.

CBN, (2006). "Annual Report and Statement of Accounts". Central Bank of Nigeria.

CBN Statistical Bulletin 2001, 2006 \& 2013.

Fasanya, J. O (2012). "Capital Flows-Growth Nexus in Nigeria: Has Foreign Direct Investment Played a Role in Accelerating Economic Growth?”. Journal of sustainable Development in Africa, 14(8): 34-54.

Graham, E. M. (1995). "Foreign Direct Investment in the World Economy". IMF World Economic and Financial Survey. Pp. 120-135.

Gujarati, D. N (2003). “Basic Econometric” McGraw-Hill Higher Education, International edition. Pp. 807-846.

Jhingan, M. L. (2002). "Macroeconomics Theory" $10^{\text {th }}$ edition. Vrinda Delhi pp 603.

Li, W. \& Liu, X (2005). Foreign Direct Investment and Economic Growth: An increasingly endogeneous relationship. World Development. 33(3). Pp. 393-407.

Mankiw, G. N (2003). "Macroeconomics”. Business Process Management Journal, vol.11 No.2 pp. 109-122.

Okeke, R. C, Ezeabasili, V. N. \& Nwakobi, C. N (2014). "Foreign Direct Investment and Economic Growth in Nigeria: An Empirical Evidence". International Journal of Innovative Research in Management Issues 3, vol. 3.

Oloyede, J. \& obamuyi, T. (2000). "The Impact of Direct Investment on the Nigeria Economy", Nigeria Journal of Banking and Financial Issues, vol. 3 No 1.

Todaro, (2000). "Economic Development in Third World". Longman Publisher.

Todaro, M. \& Smith, S. (2003). "Economic Development", $8^{\text {th }}$ Edition, Pearson education, Asia.

UNCTAD (2006). "World Investment Report", Geneva: United Nations Conference on Trade and Development. 